This article was downloaded by: [University of Cambridge]

On: 09 February 2012, At: 08:03

Publisher: Routledge

Informa Ltd Registered in England and Wales Registered Number: 1072954 Registered

office: Mortimer House, 37-41 Mortimer Street, London W1T 3J H, UK

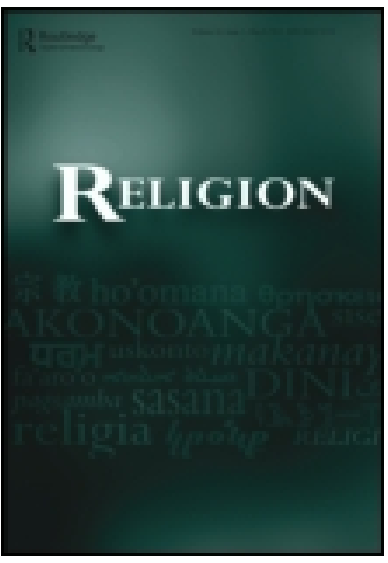

\title{
Religion
}

Publication details, including instructions for authors and subscription information:

http:// www.tandfonline.com/loi/ rrel20

\section{On the market: consumption and material culture in modern Chinese Buddhism}

\author{
Francesca Tarocco ${ }^{a}$ \\ a NYU Shanghai Research Institute, Science Building A303, East \\ China Normal University, 3663 Zhong Shan Bei Road, Shanghai, \\ China, 200062
}

Available online: 22 Dec 2011

To cite this article: Francesca Tarocco (2011): On the market: consumption and material culture in modern Chinese Buddhism, Religion, 41:4, 627-644

To link to this article: http:// dx.doi.org/ 10.1080/ 0048721X.2011.624698

\section{PLEASE SCROLL DOWN FOR ARTICLE}

Full terms and conditions of use: http://www.tandfonline.com/page/terms-andconditions

This article may be used for research, teaching, and private study purposes. Any substantial or systematic reproduction, redistribution, reselling, loan, sub-licensing, systematic supply, or distribution in any form to anyone is expressly forbidden.

The publisher does not give any warranty express or implied or make any representation that the contents will be complete or accurate or up to date. The accuracy of any instructions, formulae, and drug doses should be independently verified with primary sources. The publisher shall not be liable for any loss, actions, claims, proceedings, demand, or costs or damages whatsoever or howsoever caused arising directly or indirectly in connection with or arising out of the use of this material. 


\title{
On the market: consumption and material culture in modern Chinese Buddhism
}

\author{
Francesca Tarocco* \\ NYU Shanghai Research Institute, Science Building A303, East China Normal University, 3663 \\ Zhong Shan Bei Road, Shanghai, China 200062
}

\begin{abstract}
For many Chinese speakers in China and elsewhere, experiencing or connecting with matters of religion often includes mediation through or with material objects. Such mediation is readily accessible to larger and larger audiences and often occurs through the consumption of religious material goods, thanks also to media technologies and the Internet. In this article, the author seeks to complicate the notion that the production and consumption of novel Buddhist religious goods can be analyzed solely in terms of 'market theory.' While on the one hand the author shows that Buddhist technologies of salvation are historically associated with materiality, she also contends that the 'aura' of Buddhist-inspired modern religious goods - in the spirit of Walter Benjamin's essay 'On Some Motifs in Baudelaire' (1939) - is not so much effaced as it is reconfigured and transformed by technological mediations.

KEY WORDS Chinese Buddhism; religious goods; media and religion; consumption
\end{abstract}

For many people, experiencing or connecting with matters of religion includes mediation through or with material objects or religious goods. In modern China, such mediation, often intensely personal, is readily accessible to larger and larger audiences. But what religious goods are consumed and who consumes them? At the more general level, a growing body of evidence suggests that religious goods are reaching millions of Chinese and Sinitic-language-speaking audiences both in their homes and hand-held devices, through all manner of audiovisual digital production and dissemination (Chandler 2004; Tarocco 2012). By beginning to map out the diffusion of some Buddhist-inspired religious goods, practices and strategies, I wish to complement on-going research on the qualitative/symbolic significance of religious goods and shed further light on material religion in China. I will show that modern technologies and socio-economic factors have contributed to the multiplication, accessibility and variety of Buddhist-inspired religious goods. By focusing on a few specific case studies related to the practice of Chinese Buddhism, I will argue that religious consumption is not a new or recent phenomenon. I will argue, too, that the production and consumption of religious goods defy a simple 'market-theory' model because it also encompasses Buddhist technologies

*Email: ft21@nyu.edu 
of salvation. The 'religious-economy model,' in which religious institutions are portrayed as operating within an open market, competing among themselves and with other cultural institutions for membership and support mainly through the distribution of religious 'goods' and 'rewards,' while certainly useful and instructive, does not provide a full account of Chinese people's religious preferences or choices in relation to Buddhism, and is not entirely helpful in examining patterns of religious consumption. Instead, I propose to look more closely at indigenous ideas regarding notions of mediation, efficacy (ling 靈) and traces ( $j i$ 跡), and to revisit Walter Benjamin's reflections on how mass mediation affects the aura of the original. ${ }^{1}$

The present analysis is based in part on data I gathered in China, Hong Kong and Taiwan between 1995 and the present, by interviewing religious communities' representatives and attending ceremonies, workshops and religious festivals. ${ }^{2}$

\section{Material religion in Chinese history: a brief overview of the Buddhist world}

Religious consumption is not a new or recent phenomenon either in China or elsewhere. ${ }^{3}$ Historically, Chinese Buddhists never adopted a radical rejection of the material world. On the contrary, for them 'objects render the sacred tangible and proximate. Things allow one to communicate with deities and sense their presence' (Kieschnick 2003: 23). Material culture is as fundamental to Chinese Buddhists as are writing, doctrine, texts or ritual. In fact, a deep and persisting belief in the accumulation of religious merit and in the efficacy of merit transference to others, and especially to the deceased, coupled with a preoccupation with materializing such merit and venerating sacred objects, can be seen as elements central to the practice and understanding of Chinese Buddhism. ${ }^{4}$ Jacques Gernet describes in detail many religious ceremonies taking place in the wealthy southern city of Hangzhou and capital of the Southern Song dynasty in the 13th century. On the eighth day of the fourth lunar month, city dwellers celebrated the birthday of the Buddha. They first hired boats to go out into Hangzhou's large lake and free into its waters 'a

\footnotetext{
${ }^{1}$ According to Charles Muller (2007), $j i$ can be 'the results, or after-effects of something, especially Buddhist teachings' and can often be translated simply as 'teaching.' See also Benjamin (1999a).

${ }^{2}$ Between the years 1995 and 1999, I conducted multiple interviews with the monks Guangfu and Rending of Wenshu Monastery in Chengdu, as well as with Guopang of Tiexiang Nunnery, outside Chengdu. In Hangzhou, I talked at length in 1998 and 2002 with the scholar Chen Xing, Director of the Hongyi and Feng Zikai Research Centre. In Beijing (1995-98) and Wutaishan (September 1998), during the celebrations for anniversary of two thousand years of Buddhism in China (Jinian Zhongguo Wutaishan Wuding Wenshu pusa kaiguang fahui 紀念中國五台山五頂文殊菩薩開光法會), I was lucky to share the numerous insights and profound knowledge of the Chinese Buddhist world of Professor Tian Qing (Chinese Academy of Social Sciences). In Shanghai, where I have lived for extended periods since 1999, I have continuously conversed and interviewed practitioners and visited all major Buddhist monasteries and sites, often taking part in ceremonies and rituals, together with prominent scholars and lay persons, including Qian Renkan. I have also been fortunate enough to meet Feng Zikai's daughter, Feng Yiyin and Liu Zhiping's son Liu Xueyang, and numerous laymen and laywomen, including Song Haidong and Zhu Julan. I have also conducted numerous visits to Putuoshan and to the Jingling Buddhist Press in Nanjing.

${ }^{3}$ McDannell (1995) and Moore (1994) have eloquently shown that the distribution of popular religious goods, including images of Jesus, wax crosses, morality tales and theatrical revival sermons, have been an integral part of the American religious experience since the late 1700s.

${ }^{4}$ Cf. Strickmann (1996) and Foulk and Sharf (1993-94).
} 
myriad furred, feathered and scaly animals' that had previously been purchased alive in the markets in order to acquire religious merit (gongde功德) through the 'protection of life.' Eventually, the ritual of bathing Buddhist statues took place, whereby monks poured sugared water and flower adornments on the images and then carried them in processions while asking for alms (Gernet 1962: 193). ${ }^{5}$

Visual practices are shown in early Buddhist sources as primary means of cultivating the faith, a necessary precondition for proceeding along the Buddhist spiritual path. In his recently published book, Thus Have I Seen: Visualizing Faith in Early Indian Buddhism, Andy Rotman (2008) shows how images functioned as a key for opening up Buddhist conceptualizations and ways of categorizing the world. The Buddha's image was constructed as a relic of the Buddha and the practice of making and distributing images is again viewed as a way of acquiring religious merit. One of the main raisons d'etre for the making of the 'first' image of the Buddha was to aid contemplation during the time when the Buddha would no longer be around to preach, and looking at it is said to be no different from looking at the Buddha's [actual] body (Lancaster 1974). ${ }^{6}$

In Shaping the Lotus Sutra: Buddhist Visual Culture in Medieval China, Eugene Y. Wang (2005) focuses on the medieval Chinese Buddhist images referred to as 'transformation tableaux'. These take their subjects from Buddhist scriptures, and, in particular, from specific descriptions of transformative and miraculous experiences including rebirth in a Buddhist Land, the intervention of bodhisattvas in human affairs, the transfiguration of human beings into other forms as a result of karmic consequence, images of hell, and all other events that are compelling to humans because of their liminal and numinous nature. Such images, serving ritual ends, can frequently be seen on the walls of Buddhist temples and monasteries, and were typically commissioned from artists and craftsmen by both monastic and lay patrons (Wang 2005: 119). The icon was often part of the pattern of interaction between monasteries and their patrons. Buddhist charitable organizations (yi 邑) existed as early as the Northern and Southern dynasties (420-589). Lay adherents organized themselves to finance religious activities in Buddhist monasteries, in particular the erection of monuments bearing images of Buddhas and bodhisattvas. Monks and nuns might become officers or members of these religious associations, or at least they were glad to work through patron groups. From the middle of Tang (618-907) times, similar organizations, (yishe 邑社) financed activities such as the recitation and copying of sutras and the printing and making of images. In the 9th and 10th century there were usually ten to 15 such clubs attached to one monastery (Gernet 1999: 253-277; Yang 1950). ${ }^{7}$

In Ming times (1368-1644), Buddhism was a major force, its grand ritual ceremonies and masses for the dead serving the ancestor cult at all levels of society. Buddhist monasteries and monastic precincts were important public places open to all and to a variety of pursuits.

\footnotetext{
${ }^{5}$ For the practice of liberating animals in later Buddhism cf. also J. Handlin-Smith (1999).

${ }^{6}$ Note, however, that the notion of animated icon, that predates Buddhism's spread in China, ran against elite intellectual doctrinal approaches and thus some early canonical sources indicate that images are only made so that people can 'make merit.' See especially Faure (1991 and 1996) but also Strickmann (1996), Foulk and Sharf (1993-94). Cf. also Barrett (2005).

${ }^{7}$ Cf. also Liu Shufen $(2007,2009)$.
} 
By bestowing buildings, icons, plaques, steles, and sutras, upon Buddhist monasteries, the court not only accumulated religious merit, but also linked the magnificence of the church and state, giving people remote from the capital glimpses of imperial majesty and building cultural capital on the local level. The people presumably repaid such imperial largess with loyalty and prayers for the well-being of the nation and its rulers. (Weidner 2001: 219)

Buddhist invocation rituals are performed in front of the principal icon, that is, the 'manifest body of a Buddha, bodhisattva, or other divine being that functions as the central object of devotion, the primary recipient of offerings, and a major source of the rite's efficacy' (Sharf 2002: 116). ${ }^{8}$ Bernard Faure (1996) has eloquently shown that the ritual veneration of icons must be understood in terms of ling (靈) a polysemic term that underlines all ritual practice in the Sino-Japanese Buddhist context. Ling is 'the supernatural,' the 'numinous' and, in combination, it appears as lingxiang (靈像): the 'spiritual icon' that is religiously efficacious. Ling is, in Faure's words, 'the efficacy attributed to the spirits of the dead and to invisible forces.' It encapsulates the idea of a 'force that circulates, that one can harness or lose.' In as much as it follows the logic of ling, argues Faure, the Buddhist imaginaire must be conceived of 'on the mode of the debt and the gift rather than that of belief, as act rather than thought; but also on the mode of gift-giving, as something that breaks the economic circle, moving beyond into pure loss or expenditure' (Faure 1996: 282-284).

One of Chinese Buddhists' favorite information technologies is woodblock printing, which, as T. H. Barrett has shown, had its origins in China as a medium for the reproduction of Buddhist texts, which was practiced on such a massive scale that it required a technological shift from the otherwise highly efficient manuscript culture (Barrett 2001, 2008). Initially, the short printed Buddhist texts were not meant to be read but rather were construed as relics to embody the Buddha's continued presence in the world. Commercial printing of Buddhist texts was practiced by about 900 and became widely available and accepted by all by the following century (Barrett 2008: 132). Buddhist texts, of course, could also be 'burned, drowned, eaten or hidden in inaccessible places, since their messages were not necessarily directed at human beings' (Barrett 2008: 54).

In the 20th century, with improvements in manufacturing and the development of non-print media technologies such as radio and television, Buddhist religious consumption took on new dimensions in the selling and professing of the sacred. More religious products are now available than at any other time, including a wide array of knickknacks, cards, bumper stickers, rosaries, pre-recorded liturgies and rituals, DVDs on the life of eminent Buddhist clerics and so on. All of this is often sold in Buddhist religious stores (Ashiwa 2000; Ng 2000; more on this below). Even in the 1930s, Buddhist laypersons and entrepreneurs took hold of the airwaves to broadcast the Buddhadharma (teaching of Buddhism) and rival Christian missionaries' widespread use of music and hymnody (Tarocco 2007: 116-123). Just the rise of the coastal city of Ningbo as a commercial center in the Sui-Tang

\footnotetext{
${ }^{8}$ There are several theories and several different classification systems regarding the nature of Buddha's 'bodies.' The list of ten bodies, for example, includes the body of enlightenment, the body of transformation, the body of preservation of the true teachings (these being the relics of the Buddha), the body adorned with excellent physical characteristics due to great merit, the body manifested at will according to occasion and so on, cf. Guang Xing (2005: 161).
} 
(581-907) era was accompanied by an initial flourishing of Putuoshan as a pilgrimage site, the revitalized interest in the pilgrimage to Guanyin's bodhimanda or 'place of enlightenment' in the early 20th century grew together with the emergence of Shanghai as a commercial and cultural capital, especially after steamship service made travel between the island and the city faster and more comfortable (Yu 1992). ${ }^{9}$ And it is to the world of inter-war Shanghai Buddhism as an example of the complexity of modern consumption and religious practices that I shall now turn - a world, I will argue, that defied easy categorization as either 'religious culture' or 'market culture.' Shanghai Buddhists' religious consumption overlapped multiple spheres of life, including the economic marketplace, identity formation/maintenance, participation in a religious tradition and entertainment. ${ }^{10}$

\section{'Doing' Buddhism in modern China}

I don't like Mickey Mouse and the Silly Symphonies, but it can be so different, I can do Chinese legends, do them like Buddhist paintings. (Eileen Chang, The Fall of the Pagoda [1968, originally published in Chinese in 1938]). ${ }^{11}$

The privileged setting for the modern approach to 'doing' Buddhism is inter-war Shanghai, the quintessential 'modern' Chinese city, a city run by both Chinese and foreign powers and populated by migrants and sojourners often unable to maintain strong social links to their places of origin because of ongoing wars and revolutions. Perhaps not surprisingly, many of these people were avid consumers of religious goods. In Shanghai, both private initiative and private capital drove both Buddhist laity and clerics, often functioning apart from mainstream organizations, to play a greater role in the production of imagery, the founding of temples, and the creation of spiritually potent places, both at temple compounds and elsewhere. The climate of heightened religious competition due to the perceived threat of the Protestant and Catholic missionary presence contributed to stimulate the emergence of a new type of communication tool in the form of illustrated magazines and periodicals containing (mostly) black and white drawings and photographs of Buddhist inspiration and content as well as written texts. These magazines, of which there were many, were published in relatively small numbers but had a great impact on several Buddhist communities, and still do. Their publishers perceived them as key proselytizing tools geared towards a wider dissemination of Buddhist vocabulary and imagery (Kiely 2010; Tarocco 2007; Welch 1968). ${ }^{12}$ I suggested elsewhere that, since more or less the 1920s, Chinese Buddhists became conversant with internationally circulated discourses and practices regarding the relationship between

\footnotetext{
${ }^{9}$ On pilgrimage cf. also Reader and Walter (1993); on recent attitudes to pilgrimage in Japan see Reader (1987); on new technologies and charismatic non-Western religious movements see for example Hackett (1998).

${ }^{10}$ An interesting example of Buddhist cosmopolitan modernity in Japan is the transformation of the hanamatsuri花祭 (the celebration of Buddha's birthday) into the Lumbini Festival, marking the passage from a local festival to an international one and a public mass spectacle (Snodgrass 2009).

${ }^{11}$ Here, Chang is referring to the work of the Wen brothers, pioneers of the Chinese animation industry and active in Shanghai in the 1930s.

${ }^{12}$ I suggested elsewhere that in the 1920s Chinese Buddhists became conversant with internationally circulated discourses and practices regarding the relationship between religion and the modern media. The very flexibility of the terms and the technologies involved allowed them to be translated around the globe as well as be adapted to local circumstances and to generate local meanings.
} 
religion and the modern media. The very flexibility of the terms and the technologies involved allowed them to be translated around the globe as well as be adapted to local circumstances and generate local meanings (Tarocco 2007).

It was precisely the establishment of a new readership community through the diffusion of the modern Buddhist press that offered a degree of visibility to cultural activists at a time when traditional religion was coming under increasing pressure. The wealthy business classes that developed in these communities were patrons of Buddhism. They engaged in a frenzy of construction of monasteries and Buddhist buildings that has few precedents in history. At the forefront of these activities were monks and nuns known not only for their learning or charisma but also for their fundraising and entrepreneurial talents. Never part of a cohesive movement, Chinese Buddhist cultural activists and entrepreneurs followed a more or less loose collection of ideas and practices spread over several Chinese localities where men and women who identified themselves as Buddhists enjoyed novel modes of cultural production and consumption. ${ }^{13}$ For instance, at least 149 new monasteries and halls were built in the rapidly modernizing and cosmopolitan Shanghai of the 1930s, including important complexes such as the Fazangsi, the Huguosi and the Qingliangsi. Before 1949, the city counted at least 300 Buddhist buildings staffed by some 5000 clerics. One of Shanghai's then-richest men, the Baghdad-born Silas Hardoon, who was married to a Buddhist practitioner and benefactor, built a temple and several other Buddhist buildings in his expansive Aili gardens located in downtown Shanghai (Betta 2000). ${ }^{14}$ By the late 1940s, according to a directory of the Shanghai Buddhist Association, several of the city's monasteries and shrines were located in the new Shanghainese dwellings where the majority of Shanghailanders conducted their everyday existence since the 1870s (You Yuwei 1988: 136-137).

Lay Buddhists were active entrepreneurs. We now know that for years they looked with interest at new media and that novel kinds of religious goods emerged in the interactions among Buddhism, transnational wealth and capital, and new technologies. ${ }^{15}$ James Brooks Jessup (2010) describes the genesis of two major lay Buddhist organizations in 1920s Shanghai: the World Buddhist Householder Grove and the Pure Karma Society (Fojiao jingye she 佛教淨業社). The former aimed to create a novel space for participation in lay Buddhist life by trying to unify a number of pre-existing practices as well as promoting new ones. For instance, lay Buddhists sought to institutionalize charity work, including flood relief, the running of soup kitchens and the establishment of schools. The Pure Karma Association played host to the first successful pan-Chinese Buddhist organization, the Chinese Buddhist Association founded in 1929 and dominated by Shanghai lay Buddhists. In the same period, members of the World Buddhist Householder Grove launched the Shanghai Buddhist Books publishing house

\footnotetext{
${ }^{13}$ For the religious context in China at end of the 19th century see Goossaert (2006: 307-336). For Buddhist-inspired cultural activism in pre-Communist-era Shanghai see Barmé (2002), Brooks-Jessup (2010), Tarocco (2007) and Welch (1968).

${ }^{14}$ Between 1909 and 1913, Hardoon and his wife Luo Jialing also sponsored the publication of the Chinese Canon of Buddhist scriptures, one of the largest collections of texts in the world, a huge scholarly and financial undertaking for a private individual and donor; cf. Barrett (n.d.).

${ }^{15}$ For examples of Buddhist transnational wealth and activities see Ashiwa (2000), Chandler (2004) and Snodgrass (2009).
} 
(Shanghai foxue shuju 上海佛學書局), a joint stock limited-liability corporation that, while run for profit, was solely dedicated to spreading the teachings of Buddhism through the production of Buddhist goods. In the 1930s this company had a tremendous impact on Chinese Buddhism: they produced scriptures, tracts written in the vernacular for the purpose of being more accessible to larger audiences and Buddhist periodicals with large circulations. They also produced all manner of religious paraphernalia, recorded gramophone records of Buddhist chants and sermons and began to run a Buddhist radio station (more on this below).

The wealthy layman Yang Wenhui 楊文會 (1837-1911), a keen photographer, brought photographic equipment back to Nanjing and Shanghai from his official missions to Britain and France in the late 19th century. He even provided some of the studios in Shanghai with their first cameras (Yang Buwei 1947). After this initial impulse, the use of photography in Buddhist religious portraiture and deathbed images became fairly widespread among Chinese Buddhists. In a parallel case in Tibet, as early as the 1910s, the photographic portrait existed alongside, and, to a certain extent, even replaced, the earlier iconometric codes deployed in painted ritual portraits. This is because the mimetic act of the photograph could, argues Claire Harris (1999), confer sanctity to its subject in the creation of Tibetan photo-icons, the photographic portraits of the Dalai Lama and other senior monks that are displayed in altars and shrines.

In the 1930s and 1940s, Chinese monks used photographic portraits to instruct their followers on the signs of predestination on the faces of very young children, who were then tonsured when they were as early as four years old. ${ }^{16}$ Intriguingly, prominent monks also posed for photographic portraits in the guise of the potbellied Maitreya, the Buddha of the future age. Together with the idiosyncratic arhats (luohan 羅漢), this figure is portrayed in pre-modern art and literature as a sort of divine fool, whose divinity is disguised by an eccentric physical appearance. ${ }^{17}$ There is also evidence that photographs of the 'uncorrupted' bodies of deceased monks circulated among Buddhist worshipers in China and Taiwan, where non-putrefaction has long been taken as evidence of sanctity, as witnessed by the practice of worshiping 'flesh bodies' (roushen 肉身). These are mummies of eminent monks, whose bodies are said not to have succumbed to the normal process of decomposition, of which perhaps the most famous one is that of the sixth patriarch of the Chan School, Huineng, kept at Nanhuasi in Guangdong. ${ }^{18}$ Today, followers venerate the roushen as well as the photographic portraits of the Master Xingci, who established the Fazangjiang Monastery in Shanghai in $1924 .{ }^{19}$

Hongyi 弘一 (1880-1942), one of modern China's most eminent monks, was the subject of numerous drawings by one of his favorite lay disciples, the famous visual artist Feng Zikai 豐子愷 (1898-1942). Even more intriguingly, he is portrayed in numerous photographs (Chen Xing and Zhao Changchun 1999). One of modern Shanghai's most important temples, Yufosi, displays the photographs that have acquired a special meaning among practitioners, including the memorable

\footnotetext{
${ }^{16}$ See Welch (1967: 501, n. 22).

${ }^{17} \mathrm{Cf}$. Welch (1967: 343-344 and passim). China's most famous Buddhist reformer, Taixu, among others, is also portrayed in countless photographs.

${ }^{18}$ This practice was still very common in $20^{\text {th }}$-century China, as attested by various sources, including Prip-Møller (1937: 179) and Yetts (1911: 699-725).

${ }^{19} \mathrm{C}$. the sources underlying the biography of Xingci 興慈, Chen Qubing (2002).
} 
'deathbed' photograph analyzed in an essay by Raul Birnbaum (2007). The photograph shows the monk reclining on his right side, his eyes closed, in the manner typical of the Nirvanna type of representation: the final release of the historical Buddha. In fact, the hand-written inscription over the photo informs us that this is the eminent monk's niepan ruixiang (涅槃瑞相) or 'auspicious sign of Nirvāna.' ${ }^{20}$ In a recent monograph on this topic, Sonya Lee has argued that Chinese Buddhists have been responsible for important innovations linking the historical Buddha Śākyamuni to the Buddha of the future age, Maitreya, a soteriological strategy of hope and continuity in an age dominated by the fear for the imminent end of the Dharma, the Buddhist Law (mofa 末法). ${ }^{21}$ In establishing such a connection, Chinese artists abandoned the Indic convention of placing the Parinirvāna scene solely within the visual narrative of Sākyamuni's life. This development marked the start of native interpretations of the Nirvāna paradigm (Lee 2010).

Modern Buddhists are of course aware of this parallel and there is considerable pressure in monastic circles to achieve such a death, for which special training is required (Birnbaum 2007). The photograph, argues Raul Birnbaum, is not only 'a portrait,' but also 'because it is a postmortem artifact, it finds a natural place among the remains of the master' (2007: 198), in other words, among his relics. The devotion for the remains of venerable monks, whose sanctity elevates them to Buddha status, is yet another expression of Nirvāna devotion, argues Lee (2010). Intriguingly, in Buddhist-inspired literary Chinese, when one thinks of the miraculous images (ruixiang 瑞像) - where the first character, 'auspicious,' is the same used here in the inscription on Hongyi's photograph, one is immediately reminded of the term used by the eminent Tang scholar-monk and pilgrim to India, Xuanzang (玄牀) (602-664), to refer to the very first miraculous image of Śākyamuni Buddha carved in sandalwood (cf. Soothill and Hodous [1937: 407]). ${ }^{22}$ Talking to this first image of himself, which could not only listen to him but also walk, Śākyamuni said: 'After my Nirvāna, you will serve as model to the four categories of followers' (quoted in Faure 1998: 782). ${ }^{23}$

In Buddhist Chinese, xiang (像) means 'similar,' 'semblance,' but also 'image,' 'portrait' and 'form.' Xiang (相) is an 'attribute,' a 'mark,' or a 'distinctive feature.' In this latter sense it is often used to translate the Sanskrit lakșana; a Buddha is recognized by his 32 lakșana, his 32 characteristic physiological

\footnotetext{
${ }^{20}$ The image has been reproduced in many commemorative volumes of the master's life that I have seen. Cf. Lin Ziqin (1995). It is also available online, cf. for example Thomas Hahn's http://hahn.zenfolio.com/ p368676071/h20c4842\#h20c4842.

${ }^{21}$ On mofa-related teachings, practices and prophecies of decline cf. Hubbard (1999).

${ }^{22}$ Stories about miraculous images (ruixiang) were recorded in various text sources compiled during the sixth and seventh centuries and range from the Biographies of Eminent Monks (Gaoseng zhuan 高僧傳, T.2059, 50: 322-424) by Huijiao 慧晈, from around 531, to the Assembled Records of Response of the Three Jewels in the Spiritual Realm (Ji shenzhou sanbao gantong lu集神州三寶感通錄, T\#2106, 52: 404-435), compiled in 664 by Daoxuan 道宣(596-667).

${ }^{23}$ The Biographies of Eminent Monks (Gaoseng zhuan) was completed around 530 by Huijiao (497-554). Earliest references to the creation of a first image by Udyāna (優填 or 優陀延王), King of Vasta, are found in two canonical scriptures on image making: the Sutra Spoken by the Buddha on the Making of Buddha Images (佛說作佛形象經, T. 692, 16:788a-c) translated in the Later Han-dynasty (25-220), and the Sutra Spoken by the Buddha on the Retribution of Merits [Attained by] Making and Installing Buddha Images (佛說造立形象福 報經, T. 693, 16:788c-790a) translated in the Eastern Jin dynasty (317-420).
} 


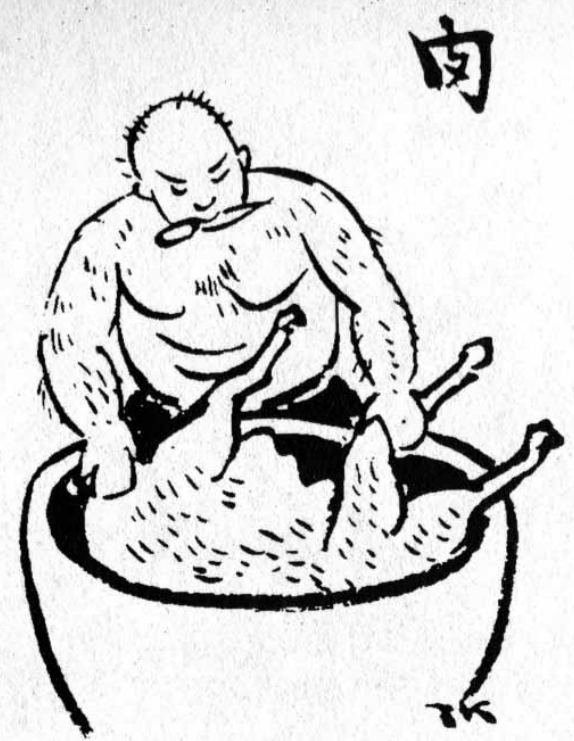

Figure 1. The cartoon (manhua) 'Meat'.

Source: Feng Zikai, Zikai manhua quanji, 5 vols, Shanghai: Kiaming Shudian, 1945.

marks. ${ }^{24}$ These semantic layers seem to come to the surface in the understanding of photographic portraits of Buddhist masters and perhaps, more generally, in all photography-related terminology in modern China. As in Buddhism, a photograph in modern Chinese can be xiang and xiang, an image, a liking, a semblance, but also a distinctive feature and a trace. ${ }^{25}$

Memorial photos of masters, together with the reliquaries containing their crematory relics (sheli[zi] 舍利子, śarìra) serve, among other things, as a 'constant remainders of transience' (Birnbaum 2007: 184). At the same time, they can also be seen, since practitioners choose to pair them with sheli, a more traditional form of imagery, as a modern medium partaking of Chinese Buddhism's strategies of presence. The standardized production of icons and consequent production of a sort of commodity fetishism is not a new phenomenon, as studies on medieval Japan have recently demonstrated. This shift, argues Bernard Faure, marked 'a watershed in icon production (and perhaps in icon reception).' But the cultic value of the image does not disappear because 'the dissemination of power or sacrality (ling) is what justifies the multiplication of icons in the first place. Depending on circumstances, this dissemination can reflect (or produce) both an increase and a decrease in belief' (Faure 1998: 802). The Buddhist tradition, while constantly preoccupied with authenticity and origins, has also actively explored the possibilities intrinsic in all kinds of traces, remains, relics, images and shadows.

${ }^{24}$ Cf. Muller (2007), http://buddhism-dict.net/ddb.

${ }^{25}$ Cf. A New Century Chinese Dictionary (2002: 1781-1782). 


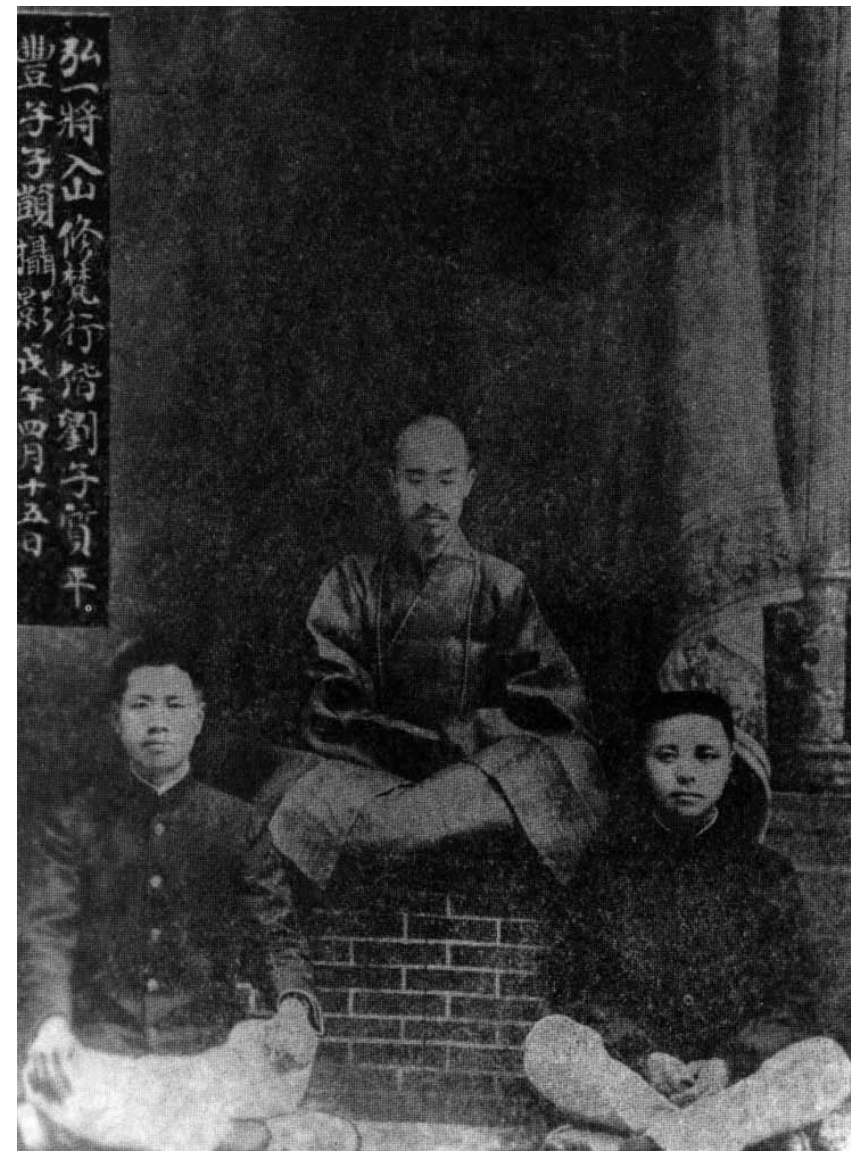

Figure 2. The photograph, taken shortly after Hongyi's ordination in 1918, portrays the monk sitting on a raised platform flanked by his pupils Feng Zikai (right) and Liu Zhiping. Source: Lin Ziqin, Hongyi dashi nianpu, Shanghai: Honghuayuan, 1944.

In the 1930s, Hongyi energetically participated in not only the production of his own photographic traces, but also in the production of other Buddhist religious goods both traditional (calligraphies and couplets to be displayed at monasteries) and modern (including books of Buddhist-inspired comics [manhua], as well as newly composed songs and hymns) to be purchased in the marketplace. Together with his disciple, Feng Zikai, he published the Drawings to Protect Life (Husheng huaji 護生畫集), which contained his calligraphy and choice of texts, as well as images that contributed to visualizing for modern urban audiences traditional Buddhist preoccupations with vegetarianism and the 'protection of life' (Barmé 2002; Tarocco 2007). These images are available today in a plurality of formats and through a variety of media, from morality books freely distributed in monasteries to the Internet. Contemporary Buddhists, moreover, endlessly reproduce and consume the voice-based compositions pioneered by Hongyi in the 1930s. Embracing musical modernity and reproduction technologies, he and other Buddhist activists chose to incorporate some elements of the modern global soundscape (Western-influenced and mass-mediated) in their own musical idiom (Jones 1999; Kraus 1989; Tarocco 2007). While marking a departure from traditional liturgical 


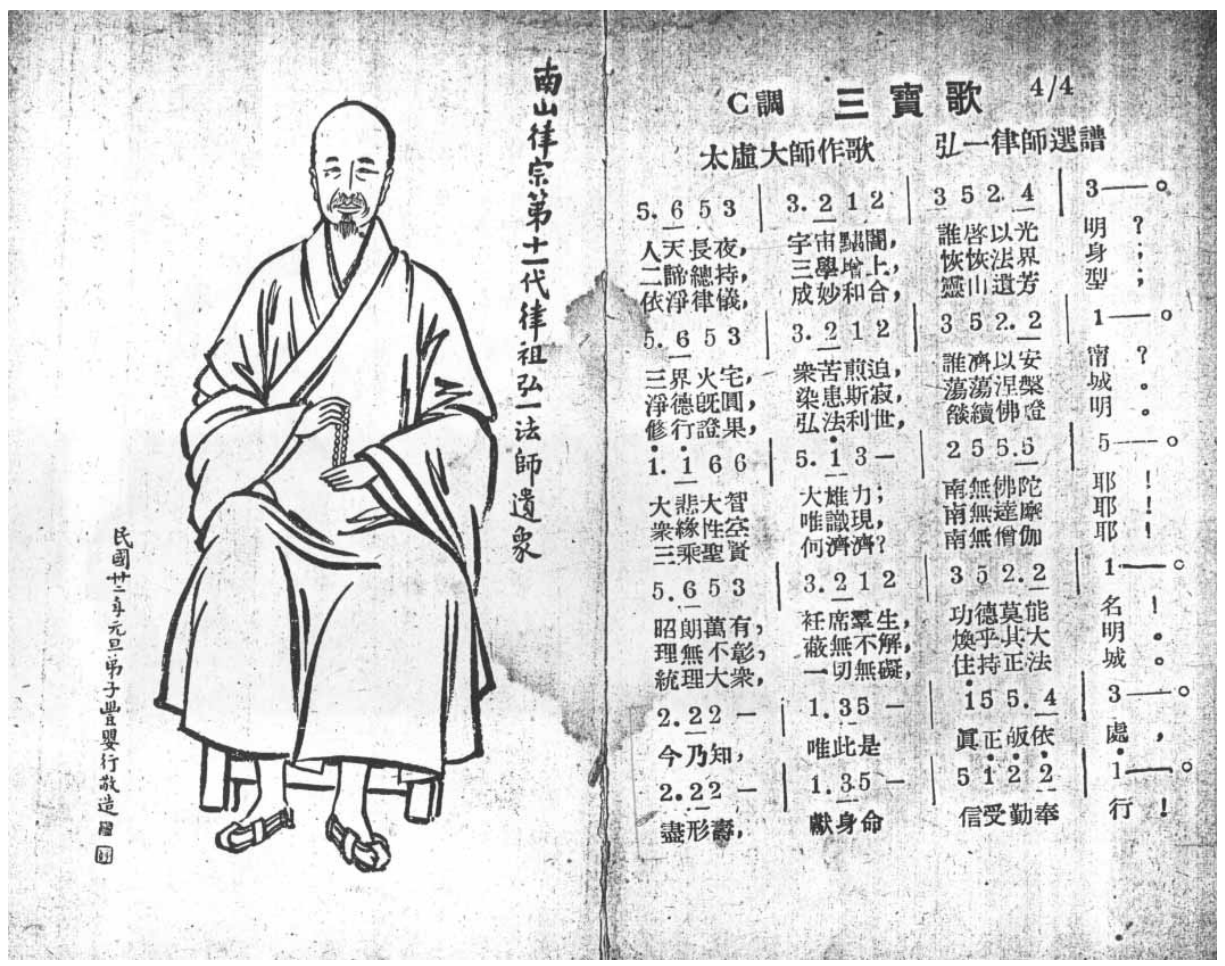

Figure 3. The score notation of The Song of the Three Jewels and Hongyi in a 1930s drawing penned by Feng Zikai.

Source: Chen Faxiang, ed., Renjian ai wanqing, Shanghai: Dafalun shuju, 1948.

music, the compositions and songs they wrote creatively adapted traditional Buddhist language, teachings and imagery for audiences of modern consumers. Already in 1934, a Buddhist association operated its own radio station in Shanghai called the Buddha's Voice (Foyin diantai 佛音電台), one of the first Buddhist radio stations in the world. It broadcast daily a mixture of phonograph recordings of liturgical chants (fanbai) and of Hongyi's and others' newly composed Buddhistinspired songs to a sympathetic audience. We also know that in 1935-36, a Buddhist publishing house produced two sets of vinyl records (fohua changpian 佛化 唱片), now unfortunately lost, but there may have been many more (Tarocco 2007: 129-130). The most famous of these songs is The Song of the Three Jewels (Sanbaoge 三寶歌) written by Hongyi together with the prominent activist monk Taixu 太虛 (1890-1947) in the 1930s. In the intervening decades since it was initially printed in a popular Buddhist magazine, it has continuously been sung, printed, recorded and adapted to shifting identity needs and religious and musical tastes, especially since the 1990s: a period of nostalgic remembrance of pre-1949 Shanghai that swept post-Maoist China and post-colonial Hong Kong. In 1990, the Shanghai Music Publishing House produced an elegantly packaged critical anthology entitled The Collected Songs by Li Shutong-Dharma Master Hongyi (Li ShutongHongyi fashi gequ quanji 李叔同弘一法師歌曲全集), a work that ushered in several other Hongyi-related religious goods. Work on the anthology was carried out by a few personalities of the Shanghai Buddhist world and carried out under the 
aegis of governmental bodies in charge of religious affairs, namely the Bureau for Religious Affairs of Shanghai (Shanghai zongjiaosuo 上海宗教所), the Chinese Buddhist Association (Zhongguo fojiao xiehui 中國佛教協會) and the local Shanghai Buddhist Association (Shanghai fojiao xiehui 上海佛教協會). ${ }^{26}$

Among the contributors to the volume were Lin Ziqin, a prominent Buddhist layman and author of the standard Buddhist biography of Hongyi (Hongyi fashi nianpu), and two musicologists of the Shanghai Conservatory and Buddhist cultural activists, Lin Peian and Qian Renkang. In 1997, the French music label Ocora released a CD with the title Hymns to the Three Jewels, curated by the musician and Chinesemusic expert François Picard. The CD originated from a series of actual ceremonies organized at the Nanhai Monastery in central China, explicitly aimed at rivaling 'the ever-increasing influence of popular music and karaoke.' Today, the song is available in digital format through a number of retailers immediately associated with Buddhism, including shops attached to monastic compounds, but it is also found in mainstream music and audiovisual stores and, of course, through various Internet websites.

European-style symphonic music, karaoke-style chanting and CDs of pop Buddhist-inspired tunes are only a few of the many faces of the contemporary world of audiovisual Buddhism. ${ }^{27}$ Interestingly, the influence of Western musical idioms and theories, and of modern, mass-mediated songs, has determined a number shifts in the perception of the past musical heritage and in the performance of traditional ritual repertoires. As retailers have invented various labels to identify 'ethnic' and 'world' music for listeners who seek a more varied, exotic musical fare, a new market is emerging today for 'Buddhist music' (fojiao yinyue 佛教音樂) in China and the Chinese-speaking Buddhist world. Evidence suggests that increasingly large audiences consume a plethora of Buddhist goods, including the comics, photographs, songs, drawings and calligraphies associated with Hongyi and Feng Zikai. As in pre-modern China the possession of the portrait of a Chan master was proof of a karmic connection between the subject of the portrait and the owner of the portrait itself; the collection of spirit tablets and halls in Chan monasteries were seen as a 'stockpile of charisma' (Sharf 1992), today's practitioners may be equally compelled to own a photographic portrait/icon of a modern eminent master, to purchase a collection of their sermons, or a CD with their musical compositions. While the mechanism of efficacy remains the same, Buddhist goods are more diverse and more available than in the past, especially to those who do not belong to the economic and social elites.

\section{Conclusion: 'doing' Buddhism in the Chinese digital age}

Mediation through or with material objects is crucial to the practice of Chinese Buddhism. Unique in the modern and postindustrial eras, however, is the fact that such mediation can be highly personal and readily accessible to larger and larger audiences. The multiplication and diversification of the goods that are produced and consumed and of the motivations of those that produce and consume them further complicates any attempts at easy generalization.

A profusion of Buddhist images and sounds surround modern East Asia (Chandler 2004; Ng 2000; Tarocco 2007). This is far from new phenomenon, for the

\footnotetext{
${ }^{26}$ Cf. Qian Renkang (1995) and Qian Renkang et al. ed. (1990).

${ }^{27}$ Interview with the layman Liu Xueyang, Shanghai, 12 August 1999. Interview with the cleric Shi Rending, Chengdu, 13 April 1996.
} 
production, worship and veneration of 'empowered' objects and the ritual uttering of magic formulas and chanting of scriptures have been and still are key Buddhist practices, even before modern technologies and travel, among other factors, allowed for their seemingly endless multiplication. In the Chinese digital age, with its unprecedented amounts of economic power at the individual level, choices in Buddhist religious consumption will grow all the more important and could even transform how the religious and the sacred are experienced. Buddhist-inspired religious experiences, which are so central to millions of Chinese and Sinitic-language-speaking communities in Taiwan, Hong Kong, Singapore and Chinese America, will need to be understood in more holistic and fluid way than the 'religious economy model' affords. Chinese Buddhism displays a vibrant religious goods culture, from shops selling 'Buddhist artifacts' (佛教文 物), very prominently in Taiwan, but increasingly in China's metropolitan areas as well (Shanghai, Hangzhou, Suzhou, for example) to their Internet outlets that have embraced the rules of globalization and e-commerce. Monasteries in China now market such goods as well (e.g., http://ltc.bailinsi.net/default.lq). Some famous monasteries prominently display the link to their section on religious merit (gongde maoming) on their home page, eventually listing the monies given by each named donor for the 'purchase' of his or her religious good of choice (e.g., Donglingsi in Jiangxi province, http://gd.donglin.org/gdfm/). There are several examples of Internet-based versions of traditional ritual practices. For instance, it is now possible to purchase virtual votive candles (e.g., http://www. 093.org.tw/content/servies/servies06.asp) or donate money to have a manuscript digitalized for the International Dunhuang Project at the British Library and then transfer the merit for the act to one's parents (http://idp.bl.uk/forms/ sponsorSutraChoice.a4d).

Have shifts in the production and consumption of aural and visual Buddhist goods influenced ritual behavior? Is modern technology affecting the way in which Buddhism is learned, transmitted and practiced? Are modern Buddhist goods produced in response to marketplace's logics and strategies? While the answer to these questions may be yes, I argue that Buddhist religious goods continue to function and be meaningful in ways that are unrelated to the 'religious economy model.' Ethnographic data, for instance, points to the fact that mass-produced goods, from a CD to photograph, can be viewed as a sort of 'spiritual emanation' of a Buddhist cleric or layperson who possess a special charisma connected with what practitioners describe as a profound understanding of the Buddhist teachings ( $f \circ f a$ 佛法), and/or piety and ascetic practice (or 'virtuous practice' dexing 德行). ${ }^{28}$

The contemporary production of some Buddhist goods recalls Walter Benjamin's discussion of The Work of Art in The Age of Mechanical Reproduction (1999). Mass-produced objects and religious goods, devoid of a context of ritual production, may be regarded as less sacred, powerful or efficacious than, say, an amulet produced with magical incantations. This much, Benjamin would have predicted: the mass-produced object, purchased in the market, lacks the aura of one empowered in the context of ritual production. And yet, some mass-produced objects can still be

\footnotetext{
${ }^{28}$ Interview with the layman Liu Xueyang, Shanghai, 12 August 1999. Interview with the cleric Shi Rending, Chengdu, 13 April 1996.
} 
activated through the ritual master's magic and power. Intriguingly, in a later essay, Some Motifs in Baudelaire (1999), Benjamin himself seems to have changed his mind on the 'loss of aura' and expresses a rather more positive view on the reproduction process and its relationship with 'practice,' one that seems to echo contemporary Buddhist practices in China and East Asia.

\begin{abstract}
If we designate as aura the associations which, at home in the mémoire involontaire, tend to cluster around the object of a perception, then its analogue in the case of a utilitarian object is the experience which has left traces on the practiced hand. The techniques based on the use of the camera and of subsequent analogous mechanical devices extend the range of the mémoire volontaire; by means of these devices they make it possible for an event at any time to be permanently recorded in terms of sound and sight. Thus they represent important achievements of a society in which practice is in decline. (Benjamin 1999b: 182)
\end{abstract}

Modern religious consumers engage with a plethora of piously coded objects marketed in an ever-shifting landscape of faith, ritual action and consumption. In today's Shanghai, for instance, one can eat vegetarian Buddhist food at the Buddhist Merit Grove vegetarian restaurant (Gongdelin功德林, also known by its English name, 'Godly') every day. In so doing, one appropriates the logic of calendrical ritual abstinence from meat in order to pursue a more personal ideal of health, as well as of religious purity and piety. ${ }^{29}$

Charisma and aura find new ways to infuse themselves into mass-produced artifacts, and 'sound' becomes a powerful icon that represents the 'voice' of the Buddha (foyin佛音). Increasingly popular among Buddhists is an electronic device (nianfoji 念佛機) that can continuously reproduce the liturgical recitation of Buddha's names and be conveniently placed anywhere, from a car or to a domestic altar. Today, many Shanghai urbanites I have talked to are interested in purchasing Buddhist religious goods: not only rosaries, candles and dharma musical instruments, but also CDs, DVDs and Internet-based products. New media technologies (broadcasting, recording), moreover, become ways of extending a Buddhist soundscape (a liturgy, a sermon) beyond its original spatiotemporal occurrence. In this way, Buddhist-inspired pious commodities and the people who use them defy discrete conceptions of materiality by attempting to construct piety and efficacy through, rather than outside of, consumption. Of course, it remains to be seen if Chinese Buddhists, in a similar way to others who have embraced a particular kind of religious mediation, will eventually have doubts or even distrust their chosen technologies, digital ones in particular. ${ }^{30}$

\title{
Acknowledgement
}

I wish to thank two anonymous reviewers for their detailed comments on earlier drafts of this paper. I also would like to express my gratitude to Christian Meyer, Thoralf Klein and Thomas Jansen for their valuable suggestions and for organizing the workshop that led to this publication, as well as to the other participants of the workshop, in particular Peter van der Veer, Joachim Gentz, David Palmer, Vincent

\footnotetext{
${ }^{29}$ Interviews with customers of Gongdelin restaurant, Shanghai, May 2010. On Buddhist vegetarian ideals and practices in China see Kieschnick (2005).

${ }^{30}$ For a pioneering study on religion and the Internet in Japan see Baffelli et al. (2010).
} 
Goossaert and Wendy Dosset for their feedback and for helping me to refine my ideas.

Francesca Tarocco teaches Chinese Religious History at New York University in Shanghai and is one of the founding fellows of the Institute for Shanghai Studies at NYU in Shanghai. She is the author of The Cultural Practices of Modern Chinese Buddhism: Attuning the Dharma (2007), and is currently working on a monograph entitled The Re-enchantment of Modernity: Buddhism and Photography in Modern China.

\section{References}

A New Century Chinese-English Dictionary. 2002. Beijing: Waiyu jiaoxue yu yanjiu chubanshe, 1781-1782. Anderson, Benedict. 1983. Imagined Communities. New York: Verso.

Ashiwa, Yoshiko. 2000. Dynamics of the Buddhist Revival Movement in South China: State, Society and Transnationalism. Hitotsubashi Journal of Social Studies 32: 15-31.

Baffelli, Erica, Ian Reader, Birgit Staemmler, eds. 2010. Japanese Religions on the Internet: Innovation, Representation, and Authority. London and New York: Routledge.

Barmé, Geremie. 2002. An Artistic Exile: A Life of Feng Zikai (1898-1975). Berkeley: University of California Press.

Barrett, T.H. (n.d.). Buddha's Word in Modern China: An Introduction to the Modern Chinese Buddhist Canon, unpublished manuscript.

Barrett, T.H. 2001. The Rise and Spread of Printing: A New Account of Religious Factors. London: School of Oriental and African Studies, Working Papers in the Study of Religions.

— . 2005. The Religious Meaning of Buddhist Sculpture in its Cultural Setting: The Buddha Images of Qingzhou in Light of Recent Scholarship. Buddhist Studies Review 22/1: 44-69.

- 2008. The Woman who Discovered Printing. New Haven and London: Yale University Press.

Benjamin, Walter. 1999a. Of Some Motifs in Baudelaire. In Walter Benjamin. Illuminations. London: Pimlico, 211-244. First edition 1939.

- 1999b. The Work of Art in the Age of Mechanical Reproduction. In Walter Benjamin. Illuminations. London: Pimlico, 211-244. First edition 1936.

Berger, John. 1972. Ways of Seeing. London: Penguin.

Betta, Chiara. 2000. Myth and Memory: the Chinese Portrayal of Silas Aaron Hardoon, Luo Jialing and the Ali Garden between 1924 and 1995. In From Kaifeng ... to Shanghai: Jews in China, ed. Roman Malek, Monumenta Serica Monograph Series 46, Nettetal: Steyler Verlag, 377-400.

Birnbaum, Raul. 2007. The Deathbed Image of Master Hongyi. In The Buddhist Dead: Practices, Discourses, Representations, ed. Bryan J. Cuevas and Jacqueline I. Stone. Honolulu: University of Hawai'i Press.

Brooks-Jessup, James. 2010. The Householder Elite: Buddhist Activism in Shanghai, 1920-1956. Ph.D. Dissertation, University of California, Berkeley.

Chandler, Stuart. 2004. Establishing a Pure Land on Earth: The Foguang Buddhist Perspective on Modernization and Globalization. Honolulu: University of Hawai'i Press.

Chang, Eileen. 2010. The Fall of The Pagoda. Hong Kong: Hong Kong University Press.

Chen Xing 陈星, Zhao, Changchun 赵长春. 1999. Hongyi Dashi Yingji 弘一大师影集. Jinan: Shandong huabao chubanshe.

Chen Qubing 陳去病. 2001. Xingci fashi nianpu 興慈法師年譜. Beijing: Zongjiao wenhua chubanshe.

Cho Bantley, Francisca. 1989. Buddhist Allegory in the Journey to The West. The Journal of Asian Studies 48/3: 512-524.

Dudbridge, Glen. 1970. The Hsi-yu chi: A Study of Antecedents to the Sixteenth Century Chinese Novel. Cambridge: Cambridge University Press.

Faure, Bernard. 1991. The Rhetoric of Immediacy: a Cultural Critique of Chan/Zen Buddhism. Princeton, NJ: Princeton University Press.

_. 1996. Visions of Power: Imagining Medieval Japanese Buddhism, trans. Phyllis Brooks. Princeton, NJ: Princeton University Press.

- 1998. The Buddhist Icon and the Modern Gaze. Critical Inquiry 24(Spring 1998): 768-813.

Foster, Hal. 1985. Recodings: Art, Spectacle, Cultural Politics. Seattle: Bay Press. 
Foulk, T.Griffith, Robert H. Sharf. 1993-94. On the Ritual Use of Ch'an Portraiture in Medieval China. Cahiers d' Extreme-Asie 7: 149-219.

Gernet, Jacques. 1962. Daily Life in China on the Eve of the Mongol Invasion, 1250-1276. Stanford: Stanford University Press. First French edition 1959.

- 1999. Buddhism in Chinese Society: An Economic History from the Fifth to the Tenth Centuries, trans. Franciscus Verellen. New York: Columbia University Press.

Goossaert, Vincent. 2006. 1898: The Beginning of the End for Chinese Religion? The Journal of Asian Studies 65/2: 307-336.

Guang Xing. 2005. The Concept of the Buddha. London: Routledge.

Hackett, Rosalind. 1998. Charismatic/Pentecostal Appropriation of Media Technologies in Nigeria and Ghana. Journal of Religion in Africa 28/3: 258-277.

Harris, Clare. 1999. In the Image of Tibet: Tibetan Painting after 1959. London: Reaktion Books.

Hubbard, Jamie. 1999. A Tale of Two Times: Preaching in the Latter Age of the Dharma. Numen 46/2: 186-210.

Jerolmack, Colin, Douglas Porpora. 2004. Religion, Rationality and Experience: A Response to the New Rational Choice Theory of Religion. Sociological Theory 22/1: 140-160.

Jones, Andrew F. 1999. The Gramophone in China. In Tokens of Exchange: The Problem of Translation in Global Circulation, L.H. Liu ed. Durham and London: Duke University Press, 214-236.

Jones, Andrew F. 2001. Yellow Music: Media Culture and Colonial Modernity in the Chinese Jazz Age. Durham and London: Duke University Press.

Jones, Charles B. 1990. Buddhism in Taiwan: Religion and the State 1660-1990. Honolulu: University of Hawaii Press.

Kiely, Jan, eds. 2010. Spreading the Dharma with the Mechanized Press: New Buddhist Print Cultures in the Modern Chinese Print Revolution, 1865-1949. In From Woodblocks to the Internet: Chinese Publishing and Print Culture in Transition, 1800-2008, Christopher Reed and Cynthia Brokaw ed. Leiden: E.J. Brill, 185-211.

Kieschnick, John. 2003. The Impact of Buddhism on Chinese Material Culture. Princeton, NJ: Princeton University Press.

- 2005. A History of Buddhist Vegetarianism in China. In Of Tripod and Palate: Food, Politics and Religion in Traditional China, ed. Roel Sterckx. New York: Palgrave-Macmillan Press, 186-212.

Kraus, R.C. 1989. Pianos and Politics in China: Middle Class Ambitions and the Struggle Over Western Music. New York and Oxford: Oxford University Press.

Lee, Sonya. 2010. Surviving Nirvana: Death of the Buddha in Chinese Visual Culture. Hong Kong: Hong Kong University Press.

Lewis R. Lancaster. 1974. An Early Mahayana Sermon about the Body of the Buddha and the Making of Images, Artibus Asiae 36, no. 4: 287-291.

Lin, Ziqin 林子青. 1995. Hongyi fashi nianpu 弘一法師年譜. Beijing: Zongjiao wenhua chubanshe, 2nd edn. Original edition 1944.

Liu, Shufen 劉淑芬. 2007. “Zhonggu fojiao zhengce yu sheyi de zhuanxing” 中古佛教政策與社邑的轉 型. Journal of Tang Studies 唐研究 13: 241-299.

- 2009. Xianghuo yinyuan, Bei chao de fojiao jieshe" 香火因緣北朝的佛教結社. In Zhongguoshi xinlun: Jiceng shehui fence 中國史新論, 基層社會分冊, ed. Huang Kuanzhong and 黄寬重, Taipei: Academia Sinica and Lianjing Publishing, 219-272.

McDannell, Colleen. 1995. Material Christianity: Religion and Popular Culture in America. New Haven, CT: Yale University Press.

McDermott, Joseph. 2005. The Ascendance of the Imprint in China. In Printing and Book Culture in Late Imperial China. Cynthia J. Brokaw and Kai-Wing Chow ed. Berkeley and Los Angeles: University of California Press, 55-106.

McMahon, David. 2008. The Making of Buddhist Modernism. Oxford: Oxford University Press.

Mitchell, W.J. Thomas. 2002. Showing Seeing: A Critique of Visual Culture. Journal of Visual Culture 1/2: 165-181.

Moore, R. Laurence. 1994. Selling God: American Religion in the Marketplace of Culture. New York: Oxford University Press.

Morgan, David. 1999. Visual Piety: A History and Theory of Popular Religious Images. Berkeley, CA: University of California Press.

Muller, A. Charles, ed. 2007. Digital Dictionary of Buddhism. <http://buddhism-dict.net/ddb> Edition of $12 / 26 / 2007$. 
Murphey, Rhoads. 1974. The Treaty Ports and China's Modernization. In The Chinese City Between Two Words, ed. Mark Elvin and G. William Skinner, Stanford: Stanford University Press, 17-71.

$\mathrm{Ng}$, Zhiru. 2000. The Emergence of the Saha Triad in Contemporary Taiwan: Iconic Representation and Humanistic Buddhism. Asia Major 13/2: 83-105.

Prip-Møller, Johannes. 1937. Chinese Buddhist Monasteries: Their Plans and its Function as a Setting for Buddhist Monastic Life. Hong Kong: Hong Kong University Press.

Qian, Renkang 錢仁康. 1995. Fayin xuanliu 法音宣流. Shanghai: Shanghai Foxue shuju.

Qian, Renkang 錢仁康 et al., eds. 1990. Li Shutong - Hongyi fashi gequ quanji 李叔同弘一法師歌曲全集. Shanghai: Shanghai yinyue chubanshe.

Reader, Ian. 1987. From Asceticism to the Package Tour: The Pilgrim's Progress in Japan. Religion 17/2: 133-148.

Reader, Ian, George J. Tanabe, Jr. 1998. Practically Religious: Worldly Benefits and the Common Religion of Japan. Honolulu: University of Hawaii Press.

Reader, Ian, Tony Walter, eds. 1993. Pilgrimage in Popular Culture. London: Palgrave.

Rotman, Andy. 2008. Thus Have I Seen: Visualizing Faith in Early Indian Buddhism. New York and Oxford: Oxford University Press.

Schafer, Edward H. 1963. The Golden Peaches of Samarkand: A Study of T'ang Exotics. Berkeley: University of California Press.

Schopen, Gregory. 1988-89. On Monks, Nuns and 'Vulgar' Practices: The Introduction of the Image Cult into Indian Buddhism. Artibus Asiae 49/1-2: 153-168.

Shahar, Meir. 2002. Epigraphy, Buddhist Historiography, and Fighting Monks: The Case of Shaolin Monastery. Asia Major (3rd Series) 13/2: 15-36.

Sharf, Robert. 1992. The Idolization of Enlightenment: On the Mummification of Ch'an Masters in Medieval China. History of Religions 32/1: 1-31.

- 2002. Coming to Terms with Chinese Buddhism: A Reading of the Treasure Store Treatise. Honolulu: University of Hawai'i Press.

Shaw, Miranda. 1988. Buddhist and Taoist Influences on Chinese Landscape Painting. Journal of the History of Ideas 49: 183-206.

Smith, Karen. 2008. Nine Lives: The Birth of the Avant-Garde in New China. Beijing and Hong Kong: Timezone 8.

Smith, Joanna Handlin. 1999. Liberating Animals in Ming-Qing China: Buddhist Inspiration and Elite Imagination. Journal of Asian Studies, February (58.1), 51-84.

Snodgrass, Judith. 2009. Performing Buddhist Modernity: The Lumbini Festival, Tokyo 1925. Journal of Religious History 33/2: 133-148.

Sommerville, C. John. 1992. The Secularization of Early Modern England: From Religious Culture to Religious Faith. New York and Oxford: Oxford University Press.

Sommerville, C. John. 2002. Stark's Age of Faith Argument and the Secularization of Things: A Commentary. Sociology of Religion 63/3: 361-372.

Soothill, William Edward, Hodous, Lewis. 1937. A Dictionary of Chinese Buddhist Terms. London: Kegan Paul, Trench, Trubner and Co.

Strickmann, Michel. 1996. Mantras et Mandarins: le Bouddhisme Tantrique en Chine. Paris: Gallimard.

Tarocco, Francesca. 2007. The Cultural Practices of Modern Chinese Buddhism: Attuning the Dharma. London: Routledge.

- forthcoming 2012. Pluralism and its Discontents: Buddhism and Proselytizing in Modern China.

In Proselytizing and the Limits of Religious Pluralism, ed. Juliana Finucane, Michael Feener. Oxford: Oxford University Press.

Taylor, Charles. 2004. Modern Social Imaginaries. Durham, NC: Duke University Press.

Wang, Eugene Y. 2005. Shaping the Lotus Sutra: Buddhist Visual Culture in Medieval China. Seattle and London: University of Washington Press.

Weidner, Marsha Smith. 2001. Imperial Engagement with Buddhist Art and Architecture: Ming Variations on an Old Theme. In Cultural Intersections in Later Chinese Buddhism, ed. Marsha Smith Weidner. Honolulu: University of Hawai'i Press.

Welch, Holmes. 1967. The Practice of Chinese Buddhism: 1900-1950. Harvard: Harvard University Press. Welch, Holmes. 1968. The Revival of Buddhism in China. Cambridge, MA: Harvard University Press.

Yang, Buwei. 1947. Autobiography of a Chinese Woman. New York: John Day.

Yang, Fenggang. 2006. The Red, Black, and Gray Markets of Religion in China. The Sociological Quarterly 47: 93-122. 
Yang, Lien-sheng. 1950. Buddhist Monasteries and Four Money-raising Institutions in Chinese History. Harvard Journal of Asiatic Studies 13/1-2: 174-191.

Yetts, Perceval W. 1911. Notes on the Disposal of Buddhist Dead in China. Journal of the Royal Asiatic Society of Great Britain and Irlend 43/3: 699-725.

You, Yuwei 游有维. 1988. Shanghai jindai fojiao jianshi 上海近代佛教简史. Shanghai: Huadong shifan daxue chubanshe.

Yu, Anthony C. trans. 1977-1983. The Journey to the West. Chicago: University of Chicago Press, 4 vols.

Yu, Chun-fang. 1992. P'u-t'o Shan: Pilgrimage and the Creation of the Chinese Potalaka. In Pilgrims and Sacred Sites in China. Berkeley, ed. Susan Naquin and Chun-fang Yu. Berkeley, Los Angeles, Oxford: University of California Press, 202-213. 